$\begin{array}{r}\text { Phinisi Integration Review } \\ \text { Vol. 1, No.2, Agustus 2018 Hal 121-127 } \\ \text { Website: http://ojs.unm.ac.id/pir } \\ \hline\end{array}$

\title{
Pendampingan Sosial Terhadap Anak Jalanan Di Rumah Perlindungan Sosial Anak (RPSA) Kota Makassar
}

\author{
Miftahulkhair \\ Pendidikan IPS Kekhususan Pendidikan Sosiologi \\ Program Pascasarjana Universitas Negeri Makassar \\ Email: miftahulhair@gmail.com
}

\begin{abstract}
Abstrak. Penelitian bertujuan untuk mengetahui, mengkaji, dan menjelaskan (i) Tahapan Pendamping sosial yang dilakukan terhadap anak jalanan di Kota Makassar, (ii) faktor pendukung dan faktor penghambat yang terjadi dari pendampingan sosial di Rumah Perlindungan Sosial Anak (RPSA) di Kota Makassar dan (iii) dampak dari Pendampingan sosial terhadap anak jalanan di Rumah Perlindungan Sosial Anak (RPSA) di Kota Makassar. Jenis penelitian adalah kualitatif deskriptif. Teknik pengumpulan data adalah observasi, wawancara dan dokumentasi. Penentuan informan pada penelitian menggunakan Teknik purposive sampling. Dimana peneliti cenderung memilih informan secara variatif berdasarkan (alansan), yaitu jumlah informan 16 orang. Informan dari pihak tokoh masyarakat 2 orang, informan dari pihak orangtua 5 orang, informan dari pihak anak 5 orang dan RSPA 4 orang. Hasil penelitian in imenunjukkan bahwa: (i) Tahapan pendampingan yang dilaksanakan di Rumah Perlindungan Sosial Anak (RPSA) Turikale Makassar adalah Perencanaan meliputi pendampingan terhadap anakbinaan, menentukan jadwal, materi dan metode serta permainan yang akan digunakan. (ii) Faktor Pendukung Kesabaran pendampingan dalam observasi yang dilakukan oleh pendamping di Rumah Perlindungan Sosial Anak (RPSA) Turikale Makassar hubungan yang terlihat antara pendamping dengan anak jalanan yang menjadi binaan terjalin dengan baik, faktor penghambat Kurangnya tenaga pendamping yang ada dirumah perlindungan sosial anak tidak seimbang dengan jumlah anak jalanan yang menjadi binaan dan kurangnya support dari orang tua. (iii) Dampak pendampingan Anak Jalanan di Rumah Perlindungan Sosial Anak (RPSA) Turikale Kota Makassar adalah pendampingan pada anak jalanan dapat mengatasi permasalahan belajar anak jalanan, anak menjadi terampil karena deberikan fasilitas keterampilan sesuai bakatnya, dapat merubah mind set (polapikir) orang tua anak tersebut agar tidak mengulangi penyimpangan sosial terhadap anak dan mengharmonisasikan hubungan anak dan orang tua. Karena adanya proses pendampingan sehingga perilaku negatif anak tersebut dapat berkurang
\end{abstract}

Kata Kunci: Pendampingan sosial, Orangtua,Anak Jalan.

(i) (9) Ini adalah artikel dengan akses terbuka dibawah licenci CC BY-NC-4.0

(https://creativecommons.org/licenses/by-nc/4.0/)

\section{PENDAHULUAN}

Masalah sosial pada dasarnya adalah masalah yang terjadi antar warga masyarakat yang kemudian mempengaruhi proses relasi sosial. Tidak semua masalah yang ada dalam kehidupan manusia adalah masalah sosial. Munculnya masalah sosial menimbulkan kriminalitas dan perilaku menyimpang pada masyarakat. Maka dari itu anak jalanan merupakan salah satu permasalahan yang ada di 
tengah-tengah masyarakat pada saat ini. Kunci pemahaman masalah sosial adalah terletak pada kondisi yang tidak diharapkan, oleh sebab itu diperlukan upaya untuk melakukan perubahan.

Masalah Sosial kekerasan pada anak di kota Makassar dari komnas perlindungan anak (komnas PA) dari januari 2013 kekerasan fisik 294 kasus (28\%), kekerasan psikis 203 (20\%), kekerasan seksual 535 kasus (52\%) (Majalah Internal BBPPKS Kementerian Sosial RI, 2013). Kekerasan seksual tersebut terjadi di dalam rumah oleh orang-orang terdekat seperti Paman, bahkan orang tua sendiri (Incest). Rumah Sendiri Sudah tidak menjadi tempat teraman seperti sudah di persepsikan anak-anak sejak dahulu. Perlakuan salah meliputi perbuatan ataupun penelantaran yang mengakibatkan morbiditas dan mortalitas (Fakih, 2003). Jadi langkah-langkah positif tersebut memerlukan partisipasi banyak pihak seperti pendampingan sosial anak jalanan yang di lakukan oleh pekerja sosial anak satuan bakti sosial (Sakti peksos) di RPSA Kota Makassar.

Menurut Departemen Sosial RI pengertian anak jalanan adalah sebuah istilah umum yang mengacu pada anak-anak yang mempunyai kegiatan ekonomi di jalanan, namun masih memiliki hubungan dengan keluarganya. Anak jalanan seharusnya masih berada di sekolah tetapi mereka telah menjalani kehidupan jalanan untuk mencari nafkah. Aktivitas anak jalanan beraneka macam diantaranya ada yang beraktivitas sebagai pengamen, pengemis, pedagangan asongan, tukang semir sepatu dan sebagainya. Anak jalanan dilihat dari intensitas dan penyebabnya berada dijalanan tidak dapat disamakan. Dilihat dari penyebabnya, dapat dimungkinkan tidak semua anak jalanan turun kejalanan karena tekanan ekonomi, namun bisa karena pergaulan, kabur dari rumah, adanya masalah keluarga atau pilihanya sendiri.

Pada umumnya, secara sosial anak jalanan kurang diterima masyarakat dan dianggap sebagai penganggu ketertiban umum. Masyarakat biasanya hanya peduli dengan cara memberikan recehan. Marginal, rentan dan eksploitatif adalah istilah-istilah yang tepat untuk menggambarkan kondisi dan kehidupan anak jalanan. Marginal karena melakukan jenis pekerjaaan yang tidak jelas jenjang karirnya, kurang dihargai, dan pada umumnya tidak menjanjikan prospek apapun di masa depan. Rentan karena resiko yang harus ditanggung akibat jam kerja yang sangat panjang dari segi kesehatan maupun sosial sangat rawan. Adapun disebut ekploitatif karena biasanya memiliki posisi tawar-menawar (bargaining position) yang sangat lemah, tersubordinasi dan cenderung menjadi objek perlakuan yang sewenang-wenang dari ulah preman atau oknum aparat yang tidak bertanggung jawab.

Anak-anak yang hidup di jalanan, bukan saja rawan dari ancaman tertabrak kendaraan, tetapi acapkali juga rentan terhadap serangan penyakit akibat cuaca tidak bersahabat atau kondisi lingkungan yang buruk seperti tempat pembuangan sampah. Perilaku anak jalanan tidak terkendali (anarkis) karena tidak ada yang mengajari. Orangtua tidak memberikan perhatian yang sewajarnya.

Selain itu faktor ekonomi yang membelenggu kehidupan anak jalanan turut berperan. Anak-anak mengambil alih fungsi sebagai pencari nafkah di jalanan. Anak-anak jalanan patut mendapatkan kehidupan yang baik yakni memperoleh lingkungan yang baik dan dapat diterima dengan baik di dalam keluarganya. Seperti yang tercantum menurut UNICEF dalam Undang-Undang Perlindungan Anak Tentang Hak dan Kewajiban Anak Pasal 8 yakni setiap anak berhak memperoleh layanan kesehatan dan jaminan sosial sesuai dengan kebutuhan fisik, mental, spiritual dan sosial. Anak merupakan generasi penerus bangsa, jadi anak adalah sumber daya manusia (SDM) yang sangat potensial untuk dikembangkan. Anak diharapkan mampu tumbuh dan berkembang menjadi manusia yang sehat jasmani dan rohani, cerdas, bertanggung jawab dan bermoral. Anak adalah aset bangsa yang akan menentukan kelangsungan hidup, kualitas dan kemajuan suatu bangsa di waktu yang akan datang.

Keberadaan RPSA (Rumah Perlindungan Sosial Anak) sebagai kepanjangan pemerintah dibentuk untuk menjawab tingginya berbagai permasalahan anak-anak yang memerlukan perlindungan khusus. Sebagaimana diamanatkan dalam Undang-Undang Nomor 23 tahun 2002 tentang Perlindungan Anak, pasal 59. bahwa negara, pemerintah dan lembaga negara lainnya berkewajiban dan bertanggung jawab untuk memberikan perlindungan khusus kepada anak yang diterlantarkan, anak yang berkonflik hukum, anak korban pelecahan seksual dan ekonomi, anak yang menjadi korban penyalahgunaan NAPZA, anak korban penculikan, anak korban kekerasan fisik dan atau mental, anak yang menyandang cacat, anak 
korban perlakuan salah dan penelantaran termasuk anak-anak yang berada dalam situasi darurat serta anak yang berada dalam kelompok minoritas dan terisolasi. Hal tersebut diperkuat dengan terbitnya Surat Keputusan Bersama (SKB) yang ditandatangani oleh Menteri Sosial, Menteri Kesehatan, Meneg PP dan Kapolri tentang Pelayanan Terpadu Korban Tindak Kekerasan terhadap Perempuan dan Anak. SKB memberi mandat kepada Kementerian Sosial untuk mendirikan Rumah Perlindungan Sosial Anak (RPSA). Dalam fungsinya, RPSA sebagai temporary shelter dan Protection Home, memberikan perlindungan, pemulihan, rehabilitasi, advokasi, reunifikasi dan reintegrasi bagi anak yang mengalami tindak kekeraan dan perlakuan salah atau yang memerlukan perlindungan khusus, sehingga kelangsungan hidup, tumbuh kembang dan partisipasi anak dapat terjamin.

Rumah Perlindungan Sosial Anak (RPSA) Di Kota Makassar adalah lembaga yang memberikan perlindungan kepada anak yang membutuhkan perlindungan khusus dalam bentuk. 1) Temporary Sheller, yaitu unit pelayanan perlindungan pertama yang bersifat responsive dan segera bagi anak-anak yang mengalami tindak kekerasan dan perlakuan salah, atau yang memerlukan perlindungan khusus.2) Protection Home, yaitu unit pelayanan perlindungan lanjutan dari temporary sheller yang berfungsi memberikan perlindungan, rehabilitasi, pemulihan dan reintegrasi bagi anak yang memrlukan perlindungan secara khusus sehingga anak dapat tumbuh kembang sacara wajar. Anak-anak jalanan yang berada Rumah Perlindungan Sosial Anak (RPSA) Di Kota Makassar didampingi oleh pendamping sosial dengan cara memperlakukan anak seperti halnya hidup dalam suatu keluarga agar anak jalanan mampu mengenal aturan dan nilai maupun norma yang ada selain itu juga agar intensitas anak turun ke jalan berkurang bahkan lepas dari kehidupan jalanan. Pada kenyataannya anakanak ini belum sepenuhnya mampu lepas dari jalanan, beberapa waktu anak jalanan masih ke jalanan meskipun sudah tidak bekerja kembali.

Sebagai salah satu lembaga sosial yang ada di kota Makassar yakni Rumah Perlindungan Sosial Anak (RPSA) Di Kota Makassar masih melaksanakan program pendampingan bagi anak jalanan hingga saat ini. Sesungguhnya banyak penelitian mengenai pengentasan anak jalanan namun belum terlihat kondisi yang membaik maka peneliti menganggap penelitian ini masih penting untuk dilaksanakan. Peneliti mengamati bagaimana proses pelaksanaan program pendampingan anak jalanan dalam mengentaskan anak jalanan di Rumah Perlindungan Sosial Anak (RPSA) Di Kota Makassar.

Pendampingan merupakan suatu proses yang bertujuan untuk menyelesaikan permasalahan yang dihadapi oleh orang yang didampingi. Menurut Albertina Nasri Lobo (2008: 33) pendampingan yaitu sebagai suatu strategi yang umum digunakan oleh pemerintah dan lembaga non-profit dalam upaya meningkatkan mutu dan kualitas sumber daya manusia (SDM), sehingga mampu mengindentifikasikan dirinya sebagai bagian dari permasalahan yang dialami dan berupaya untuk mencari alternatif pemecahan masalah yang dihadapi.

Pendampingan adalah suatu proses relasi sosial antara pendamping dengan korban dalam bentuk pemberian kemudahan (fasilitas) untuk mengidentifiasi keutuhan dan memecahkan masalah serta mendorong tumbuhnya inisiatif dalam proses pengambilan keputusan sehingga kemandirian korban secara berkelanjutan dapat diwujudkan Departemen Sosial (2007: 4). Pendampingan merupakan sebuah suatu proses untuk meningkatkan taraf atau kualitas hidup masyarakat. Melalui suatu kegiatan yang bertujuan untuk meningkatkan sumber daya manusia (SDM), yang disesuaikan dengan kebutuhan masyarakata itu sendiri. Masyarakat yang didampingi dengan pendamping harus memiliki tujuan yang sama. Pada pelaksanaan pendampingan, pendamping hanya memberikan bimbingan, saran dan bantuan konsultatif tidak mempunyai kekuasaan lebih.

Pendampingan merupakan suatu aktivitas yang dilakukan dapat bermakna pembinaan, pengajaran, pengarahan, dalam kelompok yang lebih berkonotasi pada menguasai, mengendalikan dan mengontrol. Kata pendampingan lebih bermakna pada kebersamaan, kesejajaran, samping, menyamping dan karenanya kedudukan antara keduanya (pendamping dan yang didampingi) sederajat, sehingga tidak ada dikotomi antara atasan dan bawahan. Hal ini membawa implikasi bahwa peran pendamping hanya sebatas pada memberikan alternatif, saran dan bantuan konsultatif dan tidak pada pengambilan 
keputusan (BPKB Jawa Timur dalam Rina Erviyati (2012). Menurut Nurnita Widyakusuma (2013) pendampingan merupakan kegiatan yang diyakini mampu mendorong terjadinya pemberdayaan fakir miskin secara optimal. Perlunya pendampingan dilatar belakangi oleh adanya kesenjangan pemahaman diantara pihak yang memberikan bantuan dengan sasaran penerima bantuan.

Jadi dari pendapat di atas dapat disimpulkan bahwa pendampingan adalah suatu kegiatan untuk membantu individu atau kelompok yang didampingi untuk memecahkan masalah yang dihadapi agar dapat hidup mandiri dan berperan dalam masyarakat. Pendamping hanya berperan memfasilitasi bersama-sama individu atau kelompok dalam memecahkan masalah. Peran antara pendamping dengan yang didampingi adalah sederajat jadi dalam pelaksanaanya tidak ada istilah atasan maupun bawahan.

\section{Peran Pendampingan sosial}

Pendampingan sosial merupakan suatu strategi yang sangat menentukan keberhasilan program pemberdayaan masyarakat. "Sesuai dengan prinsip pekerjaan sosial, yakni membantu orang agar membantu dirinnya sendiri. Dalam konteks ini peranan pekerja sosial seringkali diwujudkan dalam kapasitasnya sebagai pendamping, bukan sebagai penyempuh atau pemecah masalah (problem solver) secara langsung". Khomsan (1999: 8)

$$
\text { Pendampingan sosial sangat }
$$

menentukan kerberhasilan program penanggulangan kemiskinan utamanya anak jalanan. Peran pendamping umumnya mencakup tiga peran utama, yaitu: fasilitator, pendidik, perwakilan masyarakat, dan peran-peran teknis bagi masyarakat miskin yang didampinginya.

a) Fasilitator. Merupakan peran yang berkaitan dengan pemberian motivasi, kesempatan, dan dukungan bagi masyarakat. Beberapa tugas yang berkaitan dengan peran ini antara lain menjadi model, melakukan mediasi dan negosiasi, memberi dukungan, membangun konsensus bersama, serta melakukan pengorganisasian dan pemanfaatan sumber.

b) Pendidik. Pendamping berperan aktif sebagai agen yang memberi masukan positif dan direktif berdasarkan pengetahuan dan pengalamannya serta bertukar gagasan dengan pengetahuan dan pengalaman masyarakat yang didampinginya. Membangkitkan kesadaran masyarakat, menyampaikan informasi, melakukan konfrontasi, menyelenggarakan pelatihan bagi masyarakat adalah beberapa tugas yang berkaitan dengan peran pendidik.

c) Perwakilan masyarakat. Peran ini dilakukan dalam kaitannya dengan interaksi antara pendamping dengan lembaga-lembaga eksternal atas nama dan demi kepentingan masyarakat dampingannya. Pekerja sosial dapat bertugas mencari sumber-sumber, melakukan pembelaan, menggunakan media, meningkatkan hubungan masyarakat, dan membangun jaringan kerja.

d) Peran-peran teknis. Mengacu pada aplikasi keterampilan yang bersifat praktis. Pendamping dituntut tidak hanya mampu menjadi "manajer perubahan" yang mengorganisasi kelompok, melainkan pula mampu melaksanakan tugas-tugas teknis sesuai dengan berbagai keterampilan dasar, seperti; melakukan analisis sosial, mengelola dinamika kelompok, menjalin relasi, bernegosiasi, berkomunikasi, memberi konsultasi, dan mencari serta mengatur sumber dana

\section{Fungsi Pendampingan}

Pendampingan adalah salah satu dari teknik pemberdayaan yang mempunyai fungsi penting. menurut Totok S. Wiryasaputra (2006: 88) fungsi pendampingan yakni sebagai berikut:

a) Menyembuhkan

b) Menopang

c) Membimbing

d) Memperbaiki hubungan

e) Memberdayakan (empowering),

4. Prinsip- Prinsip Pendamping Sosial

Menurut Departemen sosial (2007: 9) dalam melaksanakan tugasnya, pendamping harus berpedoman dan memegang teguh prinsipprinsip sebagai berikut:

a) Penerima (acceptance).

b) Individualisasi (individualization).

c) Tidak meghakimi (non-judgemental).

d) Kerahasiaan (confidentiality).

e) Rasional (rationality). Pendamping

\section{Tahapan Pendampingan Sosial}

Keberhasilan pendampingan tidak dapat dipisahkan dari kemampuan maupun ketrampilan yang dimiliki oleh pendamping. Keteraturan dalam melaksanakan tahapan pendampingan menjadi kunci keberhasilan. Tahapan pendampingan menurut Adi (2003: 250-258) tahapan dalam pendampingan secara umum meliputi:

a) Tahapan Persiapan 
Tahap ini mencakup penyiapan petugas (yang dimaksudkan untuk menyamakan persepsi antar anggota tim agen perubah mengenai pendekatan apa yang akan dipilih dan penyiapan lapangan, yang bertugas melakukan studi kelayakan terhadap daerah yang akan dijadikan sasaran, baik dilakukan secara informal maupun formal.

b) Tahap Assesment.

Mencakup proses pengidentifikasian masalah (kebutuhan yang dirasakan atau feltneeds) dan juga sumberdaya yang di miliki klien.

c) Tahap Perencanaan Alternatif Program atau Kegiatan

Pada tahap ini agen perubah secara partisipatif mencoba melibatkan warga untuk berpikir tentang masalah yang mereka hadapi dan bagaimana cara mengatasinya.

d) Tahap Pemformulasian Rencana Aksi

Pada tahap ini agen perubah secara partisipatif mencoba melibatkan warga untuk berpikir tentang masalah yang mereka hadapi dan bagaimana cara mengatasinya.

e) Tahap Pelaksanaan

Merupakan tahap pelaksanaan perencanaan yang telah dibuat dalam bentuk program dan kegiatan secara bersama-sama oleh masyarakat/kelompok dampingan.

f) Tahap Evaluasi

Merupakan pengawasan dari warga dan petugas terhadap program yang sedang berjalan pada pengembangan masyarakat dan sebaiknya dilakukan dengan melibatkan warga.

g) Tahap Terminasi

Merupakan tahap "pemutusan" hubungan secara formal dengan komunitas sasaran. Albertina Nasri Lombo (2003: 44-45).

6. Pendekatan Pendampingan Sosial

a) Pendekatan Ekologi dan Psikososial

Banyaknya keluarga miskin yang mengirim anak-anaknya ke Lembaga Kesejahteraan Sosial Anak menjelaskan situasi belum terbangunnya sistem ekonomi untuk mendukung keluarga-keluarga tersebut. Demikian pula semakin banyaknya panti yang dibangun tanpa memperhatikan kebutuhan anak dan keluarganya, menggambarkan nilai-nilai masyarakat yang belum sepenuhnya menyadari pentingnya pengasuhan berbasis keluarga.

Disamping itu, masih banyak faktor yang belum mendukung terlaksananya pelayanan, diantaranya terbatasnya kapasitas pengasuh anak-anak, belum optimalnya kinerja yang berwenang dalam mengatur pengasuhan anak, belum tersedianya tenaga profesional yang bekerja mendukung anak dan keluarganya, dan belum terintegrasinya bidang tugas antar berbagai pemangku kepentingan dalam pelayanan anak. Berbagai kelemahan tersebut membelajarkan tentang pentingnya kerja sama antar berbagai komponen dalam pengasuhan anak baik keluarga inti maupun keluarga akternatif dan Lembaga Kesejahteraan Sosial Anak.

Pendekatan ekologi mendasarkan pada sinergi berbagai pihak agar dapat bekerja demi kepentingan terbaik anak. Berdasarkan pemikiran tersebut, penyusunan standar dilakukan dengan mempertimbangkan situasi anak dan keluarga, serta kondisi komunitas dimana anak berada. Sejalan dengan hal itu pula, respon terhadap kebutuhan anak dan Standar Nasional Pengasuhan Untuk Lembaga Kesejahteraan Sosial Anak keluarganya harus disesuaikan dengan konteks kehidupan serta latar belakang anak dan keluarga. Selain itu diperlukan pula dukungan dari pihak-pihak lainnya agar orang tua atau keluarga dapat melaksanakan tugasnya secara tepat.

Di sisi lain, pendekatan psikososial memungkinkan pihak-pihak yang kompeten dan berkepentingan untuk melakukan asesmen yang akurat terhadap anak dan keluarganya. Hasil asesmen sangat penting bagi pengambilan keputusan pengasuhan anak dan dukungan yang perlu diberikan baik bagi anak maupun keluarganya. Melalui pendekatan ini, standar merekomendasikan dilakukannya asesmen terhadap aspek fisik (bio), psiko, sosial dan spiritual anak, orang tua atau anggota keluarga lainnya dan calon keluarga pengganti.

Secara konkrit, pendekatan-pendekatan tersebut dipraktikan dalam beberapa aspek, diantaranya adalah:

1) kesadaran bahwa anak memiliki ikatan emosional dan psikologis dengan keluarga dan komunitas tempat tinggalnya. Oleh karena itu, anak harus terus dapat menjalin ikatan ini sekalipun anak terpaksa tinggal dalam Lembaga Kesejahteraan Sosial Anak;

2) asesmen terhadap anak dan keluarga, untuk mendapat pemahaman tentang situasi pengasuhan oleh orang tua dan keluarga. Secara spesifik pendekatan ekologi juga memberikan dasar untuk melakukan asesmen secara kontekstual. Misalnya, asesmen untuk memahami cara pandang tentang pengasuhan 
dan pengaruhnya pada anak serta keluarga dalam konteks budaya tertentu;

3) pengakuan bahwa tidak ada anak yang memiliki pengalaman yang sama. Anak harus diperlakukan sebagai individu berbeda, dengan latar belakang dan pengalaman yang berbeda pula dan.

4) pendekatan ini juga memberi penekanan pada aspek praktikal, dimana standar yang diperuntukkan bagi anak dan keluarga harus berguna dan bermanfaat secara riil, dan bukan sekedar mempertimbangkan kesesuaiannya dengan program dari pemerintah atau pemangku kepentingan sebagai penyusun kebijakan.

b) Perspektif Kekuatan/Strength

Perspective

"All humans, somewhere within, have the urge to be heroic; to transcend circumstances, to develop one's powers, to overcome adversity, to stand up and be counted." Dennis Saleebey (2005)

Standar Nasional Pengasuhan Untuk Lembaga Kesejahteraan Sosial Anak Pendekatan ini terfokus pada kekuatan dan sumber daya yang dimiliki anak, keluarga juga komunitas di sekitar mereka. Kinerja tenaga profesional dibutuhkan sebatas untuk membantu memaksimalkan kekuatan dan sumber daya ini, guna menyelesaikan permasalahan yang dihadapi anak dan keluarganya serta mengoptimalkan pemanfaatan sumber-sumber di sekitar mereka. Pelayanan melalui Lembaga Kesejahteraan Sosial Anak yang di dalamnya melibatkan tenaga

profesional dimaksudkan untuk memfasilitasi dan memberdayakan anak, keluarga, dan komunitas dalam mengatasi permasalahan melalui berbagai sumber daya yang menjadi kekuatan, untuk kemudian bersama-sama mencapai tujuan yang diharapkan.

Secara konkrit, pendekatan ini diterapkan melalui beberapa prinsip:

1) Pengakuan bahwa anak, bersama keluarga dan komunitas adalah ahli sebenarnya bagi kehidupan mereka.

2) pengakuan terhadap kekuatan yang dimiliki anak, keluarga, dan komunitasnya; karenanya, perlu dilakukan identifikasi terhadap kekuatan tersebut selain identifikasi terhadap permasalahan dan kebutuhan.

3) pengakuan terhadap kapasitas pihakpihak yang selama ini tinggal dan bekerja bersama anak sebagai sumber daya yang signifikan. Disamping pengakuan terhadap perlunya keahlian profesional dari para profesional, pelatihan dan dukungan harus terus diberikan kepada pihak-pihak yang dapat berperan sebagai sumber daya tersebut.

4) pengakuan bahwa Lembaga Kesejahteraan Sosial Anak (d/h Panti Asuhan) memiliki potensi untuk mendukung terbangunnya sistem pengasuhan anak yang mendukung pengasuhan berbasis keluarga sesuai dengan kepentingan terbaik anak.

B. Anak Jalanan

1. Pengertian Anak Jalanan

Anak jalanan yaitu anak yang sebagian besar waktunya berada di jalanan atau ditempattempat umum. Secara umum anak jalanan dengan gelandangan merupakan istilah yang sama. Anak jalanan menurut Dinas Sosial Provinsi Yogyakarta adalah anak yang melewatkan atau memanfaatkan sebagian besar waktunya untuk melakukan kegiatan hidup sehari-harinya di jalan, sampai dengan umur 521 tahun. Dinsos (2010: 6).

Anak jalanan memiliki kesamaan dengan gelandangan dilihat dari cara hidupnya di jalanan. Gelandangan adalah para subyek yang tidak memiliki tempat tinggal yang tetap, juga secara yuridis maupun autentik. Di samping itu juga merupakan kelompok yang tidak memiliki pekerjaan tetap dan layak menurut ukuran masyarakat umumnya, juga termasuk orang-orang yang tidak menetap, kotor dan sebagian besar tidak mengenal nilai-nilai keluhuran Sudarsono (2004:56).

Menurut Surbakti dkk (1997) berdasarkan kajian di lapangan, secara garis besar anak jalanan dibedakan dalam tiga kelompok yakni:

a) Children on the street, yaitu anakanak yang mempunyai kegiatan ekonomi sebagai pekerja anak di jalan, namun masih mempunyai hubungan yang kuat dengan orang tua. Sebagian penghasilan anak dijalanan diberikan kepada orang tua Soedijar dan Sanusi dalam Bagong Suyanto (2010: 186). Fungsi anak jalanan pada kategori ini adalah untuk membantu memperkuat penyangga ekonomi keluarga karena beban atau tekanan kemiskinan Bagong Suyanto (2010: 187).

b) Children of the street, yakni anakanak yang berpartisipasi penuh dijalanan, baik secara sosial maupun ekonomi. Beberapa diantara anak jalanan masih mempunyai 
hubungan dengan orang tua, tetapi frekuensi pertemuan tidak menentu. Banyak diantara anak jalanan ini karena sebab kekerasan atau pergi dari rumah. Berbagai penelitian menunjukan bahwa anak-anak kategori ini sangat rawan terhadap perlakuan salah, baik secara sosialemosional, fisik maupun seksual Irwanto dkk dalam Bagong Suyanto (2010: 187). Kekerasan dapat dilakukan oleh preman atau anak jalanan yang lebih tua atau berkuasa.

c) Children from families of the street, yakni anak-anak yang berasal dari keluarga yang hidup dijalanan. Walaupun anak-anak ini mempunyai hubungan kekeluargaan yang cukup kuat, tetapi hidup terombang-ambing dari suatu tempat ketempat yang lain dengan segala resikonya. Menurut Bagong Suyanto (2010: 187) Salah satu ciri penting dari kategori ini adalah pemampangan kehidupan anak jalanan sejak anak masih bayi bahkan masih dalam kandungan.

Dari pendapat diatas dapat disimpulkan bahwa anak jalanan adalah anakanak yang beraktivitas sehari-hari atau hidup dijalanan (tidak menetap). Anak jalanan dapat juga dapat diartikan anak-anak yang hidup atau mencari nafkah di jalan meskipun masih mempunyai keluarga. Anak jalanan mempunyai tugas mencari nafkah untuk keluarganya.

2. Faktor dan Penyebab Anak Turun ke Jalan

Munculnya anak jalanan dapat disebabkan karena bermacam-macam permasalahan yang dihadapai oleh anak. Secara umum penyebab banyak faktor yang mempengaruhi anak terjerumus ke jalanan, seperti: kesulitan keuangan keluarga, atau tekanan kemiskinan, ketidakharmonisan rumah tangga orang tua, dan masalah khusus menyangkut hubungan anak dengan orang tua Bagong Suyanto (2010: 196).

Daerah yang menjadi tempat bertambahnya anak jalanan yaituperkotaan. Perkotaan merupakan lingkungan yang multikultural. Persaingan hidup yang ketat menyebabkan munculnya kalangan menengah atas maupun menengah bawah. Kalangan menengah atas dengan ekonomi kuat dan pendidikan tinggi dapat mencapai taraf hidup yang layak. Kesenjangan akan terjadi pada kalangan memengah kebawah bertahan hidup dengan stretegi survival yang beragam. Sedangkan dari kedua model tersebut masih terdapat kelompok lain yang seakan-akan terlempar dari percaturan ekonomi. Bagi kelompok ini, hanya terdapat dua kemungkinan yang dapat dilakukan, yaitu menjadi pengemis atau terjun ke dunia hitam atau kriminal Usman (2008: 143).

Menurut Sudarsono (2004: 59) penyebab interen gelandangan karena sifat malas, tidak mau bekerja, mental yang tidak kuat, adanya cacat fisik dan cacat psikis. Sedangkan faktor eksteren sebagai berikut:

a) Faktor Ekonomi. Kurangnya lapangan pekerjaan, kemiskinan dan akibat rendahnya pendapatan per kapita dan tidak tercukupinya kebutuhan hidup.

b) Faktor Geografi. Daerah asal yang minud dan tandus, sehingga tidak memungkinkan untuk pengolahan tanahnya.

c) Faktor Sosial. Arus urbanisasi yang semakin meningkat dan kurangnya partisipasi masyarakat dalam usaha kesejahteraan.

d) Faktor Pendidikan. Relatif rendahnya pendidikan menyebabkan kurangnya bekal ketrampilan untuk hidup yang layak dan kurangnya Pendidikan informal dalam keluarga dan masyarakat.

e) Faktor Psikologis. Adanya perpecahan atau keretakan dalam keluarga.

f) Faktor Kultural. Pasrah pada nasib dana adat istiadat yang merupakan rintangan dan hambatan mental.

g) Faktor Lingkungan. Pada gelandangan yang telah berkeluarga atau mempunya anak, secara tidak langsung sudah nampak adanya pembibitan gelandangan.

h) Faktor Agama. Kurangnya dasardasar ajaran agama, sehingga menyebabkan tipisnya iman.

Kemiskinan umumnya menjadi penyebab utama anak turun ke jalan. Menurut Soetomo (2008: 316) kondisi yang dikatakan kurang kondusif terutama dilihat dari situasi yang tidak mendukung proses belajar, kebiasaan hidup tidak teratur, pemilihan aspirasi yang terbatas, kebiasaan mengundur pemuasan mendadak dari kebutuhannya dan stigma yang menjadi cap keluarga miskin yang akan berpengaruh bagi kepribadian anak.

Berbagai faktor timbulnya gelandangan antara lain: factor kemiskinan (struktural dan pribadi), factor keterbatasan kesempatan kerja (factor intern maupun ekstern), factor yang berhubungan dengan urbanisasi, yang masih ditambah lagi dengan factor pribadi seperti: malas, tidak biasa disiplin; biasa hidup sesuai 
keinginan sendiri; biasa untuk tidak merasa perlu mengidahkan kaidah-kaidah normative yang berlaku umum Ramlong Naning (1982: 75). Faktor-faktor tersebut membuat terganggunya konsep fungsi sosial yang menjadikan anak-anak mempunyai beban berbagai tugas dan peranan.

Seseorang yang menjadi anak jalanan tidak hanya dilihat dari sebagai individu yang terlepas dari lingkungannya berbaur. Lingkungan anak jalanan mempunyai aturan main yang disepakati berdasarkan hasil konsensus dalam komunitas anak jalanan. Pola yang dikembangkan dalam komunitas akan mempengaruhi pemikiran dan gaya bertindak anak jalanan. Oleh karena itu memberikan penyadaran terhadap anak jalanan yang sudah dicap negatif sebagai calon-calon pelaku kriminal, dapat dilakukan dengan melakukan penguatan-penguatan lingkungan yang mampu memberikan penyadaran bagi anak jalanan sehinggga tindakan dan pemikiran bisa mengubah kesan bahwa mejnadi anak jalanan dengan selalu berada di jalanan tidak menguntungkan baginya Edi Suharto dkk (2011: 189).

Dari kesimpulan di atas anak turun ke jalanan karena adanya beberapa faktor yakni seperti kemiskinan keluarga, tekanan permasalahan dalam keluarga dan pergaulan juga dapat menjadi faktor pemicu anak menjadi anak jalanan. Pada kenyataanya tidak hanya terjadi pada anak-anak dengan ekonomi kelas bawah namun anak kalangan menengah dapat terpengaruh menjadi anak jalanan karena faktor lingkungan, emosi dan permasalahan keluarga. Lingkungan sangat membantu anak jalanan untuk mau keluar dari lingkungan komunitas atau jalanan dan hidup secara layak.

3. Penanganan ataupun Pendekatan Untuk Anak Jalanan

Penanganan terhadap anak jalanan yang selama ini dilakukan tidak mudah. Berbagai upaya dari lembaga sosial atau pemerintah sudah dilaksanakan. Untuk menangani permasalahan anak hingga ke akar-akarnya bukan dengan program yang bersifat karitatif. Sikap karitatif dengan memperlakukan anakanak jalanan sebagai objek amal dan memberikan santunan yang sifatnya temporer hanya akan melahirkan ketergantungan, bahkan meniadakan keberdayaan dan tekad self help anak jalanan itu sendiri Bagong Suyanto (2010: 200).
Menurut Tata Sudrajat (1996) pendekatan yang biasa dilakukan oleh LSM dalam penanganan anak jalanan adalah:

a) Street based, yakni model penanganan anak jalanan di tempat anak jalanan berasal atau tinggal, kemudian para street educator datang untuk berdialog, mendampingi bekerja, memahami situasi serta menempatkan diri sebagai teman. Anak-anak diberi materi pendidikan dan ketrampilan, disamping itu anak jalanan juga memperoleh kehangatan hubungan dan perhatian sehingga menumbuhkan keprcayaan satu sama lain yang berguna bagi tujuan intervensi.

b) Centre based, adalah pendekatan atau penanganan anak jalanan di lembaga atau panti. Anak-anak yang ditampung dalam program ini diberikan pelayanan seperti pada malam hari diberikan makanan dan perlindungan serta perlakuan yang hangat dari pekerja sosial. Pada lembaga yang permanen disediakan pelayanan pendidikan, ketrampilan, kebutuhan dasar, kesehatan, kesenian dan pekerjaan bagi anak jalanan.

c) Community based, yaitu model penanganan yang melibatkan seluruh potensi masyarakat, terutama keluarga atau orang tua anak jalanan. Pendekatan bersifat preventif, yakni mencegah agar anak tidak kembali terjerumus kehidupan jalanan. Keluarga diberikan penyuluhan tentang pengasuhan anak dan upaya peningkatan taraf hidup, sementara anak-anak diberi kesempatan pendidikan formal maupun informal, pengisian waktu luang, dan kegiatan lainnya yang bermanfaat. Pendekatan ini bertujuan meningkatkan kemampuan keluarga dan masyarakat agar sanggup melindungi, mengasuh, dan memenuhi kebutuahan anak-anaknya secara mandiri. Bagong Suyanto (2010: 201).

Terdapat dua hal yang harus diperhatikan sebelum melakukan intervensi ke lapangan. Pertama, modal yang dibutuhkan untuk melaksanakan program adalah sikap empati dan kesediaan meghilangkan sikap predujice terhadap anak jalanan yang sama sekali tidak menyelesaikan masalah. Kedua, sebagai manusia anak jalanan adalah anak-anak yang berhak memperoleh kesempatan untuk tumbuh berkembang secara wajar, sehingga sewajarnya jika diberi kesempatan untuk menampilkan eksistensinya sebagai bagian dari keinginan untuk beraktualisasi Bagong Suyanto (2010: 204). 
Anak jalanan berhak mendapatkan kesempatan terutama dalam bidang pendidikan. Pendidikan harus bersikap humanis yang artinya orientasi pendidikan tidak lagi pada tuntutan pelajaran tetapi lebih kepada peserta didik yang bersangkutan Munawir Yusuf (2005: 119). Dari paparan diatas dapat disimpulkan penanganan anak jalanan dapat dilakukan dengan berbagai pendekatan dan upaya-upaya penanganan yang tepat, mengingat latar belakang dari anak jalanan yang berbeda-beda.

\section{Rumah Perlindungan Sosial Anak (RPSA) \\ 1. Pengertian Rumah Singgah \\ Menurut Departemen Sosial RI (1994:}

4) Rumah Perlindungan Sosial anak adalah perantara anak jalanan dengan pihak-pihak yang akan membantu mereka. Rumah singgah merupakan proses informal yang memberikan suasana pusat realisasi anak jalanan terhadap system nilai dan norma di masyarakat.

Penelitian ini akan dilaksanakan di Rumah Perlindungan Sosial Anak (RPSA) di Kota Makassar. Terletak di jalan Langgau No. 68 Kel. La'latang Kec. Tallo Kota Makassar. Rumah Perlindungan Sosial Anak (RPSA) di Kota Makassar adalah program yang di buat oleh Dinas Sosial Makassar. Rumah Perlindungan Sosial Anak (RPSA) di Kota Makassar sampai saat ini melakukan pendampingan terhadap 75 anak jalanan yang berbeda-beda lokasi. Komitmen dari Rumah Perlindungan Sosial Anak (RPSA di Kota Makassar adalah sebagai kawasan bagi anakanak jalanan menuju kehidupan secara normal.

2. Pendampingan Rumah Perlindungan Sosial Anak (RPSA) di Kota Makassar

Fokus penelitian ini yakni pada salah satu program yang ada di Rumah Perlindungan Sosial Anak (RPSA) di Kota Makassar. Program pengentasan anak jalanan melalui pendampingan yang dilaksanakan RPSA di Kota Makassar menarik untuk ditelaah. Program ini dilaksanakan di lokasi-lokasi yang telah disebutkan sebelumnya diatas dan dilaksanakan setiap minggu. Unsur-unsur dalam pendampingan ini meliputi pemenuhan kebutuhan pangan dan nutrisi, identifikasi anak jalanan, penyuluhan dalam bidang kesehatan, pendampingan psikologis dan pendampingan advokasi anak. Sementara itu yang menjadi unsur di dalam rumah singgah meliputi Pengurus Yayasan Diponegoro, pengelola, pendamping, anak jalanan, orangtua anak jalanan dan aktivitas atau program yang di jalankan oleh rumah singgah.

Pengertian perencanaan dalam pendidikan luar sekolah menurut Sudjana (1992: 42) adalah:

a) Upaya yang berkaitan dengan penyusunan rangkaian tindakan yang akan dilakukan untuk mencapai tujuan dengan mempertimbangkan sumber-sumber yang tersedia atau disediakan. Sumber- sumber itu meliputi sumber manusiawi dan non-manusiawi. Sumber manusiawi mencakup antara lain pamong belajar, fasilitator, tutor, warga belajar, pimpinan lembaga dan masyarakat. Sumber non-manusiawi meliputi fasilitas, alat-alat, waktu, biaya, lingkungan sosial budaya, fisik dan sebagainya.

b) Merupakan kegiatan untuk mengerahkan atau menggunakan sumbersumber yang terbatas secara efisien dan efektif untuk mencapai tujuan yang ditetapkan".

\section{Landasan Teori}

1. Teori Strukturasi Anthony Giddens

Pemikiran Anthony Giddens tentang teori strukturasi "The Constitution Of Society Teori Strukturasi untuk Analisis Sosial". Teori strukturasi Anthony Giddens membahas sebuah fenomena sosial yang terjadi di dalam masyarakat secara terus-menerus, dan terpola dalam lintas ruang dan waktu.

Teori strukturasi terletak pada pemikiran tentang struktur, sistem, dan dwi rangkap struktur. Struktur didefinisikan sebagai "properti-properti yang berstruktur (aturan dan sumber daya) properti yang memungkinkan praktik sosial serupa yang dapat dijelaskan untuk eksis disepanjang ruang dan waktu, yang membuatnya menjadi bentuk sistemik." Giddens berpendapat bahwa struktur hanya ada didalam dan melalui aktivitas manusia Ritzer (2004: 510).

2. Teori Interaksi Sosial

Adapun teori yang digunakan peneliti sebagai landasan berpikir tentang pendampingan sosial terhadap anak jalanan dirumah Perlindungan Sosial (RPSA) di Kota Makassar adalah teori John Lewis Gillin, Interaksi sosial adalah hubungan-hubungan sosial yang dinamis, menyangkut hubungan-hubungan antara individu atau antar kelompok. Sementara itu, Booner menyatakan bahwa interakasi sosial adalah suatu hubungan antara dua atau lebih individu, dimana kelakuan-kelakukan individu 
tersebut mempengaruhi individu lain atau sebaliknya.

\section{METODE PENELITIAN}

Pendekatan penelitian yang digunakan dalam penelitian ini adalah pendekatan kualitatif dan metode penelitian yang dipergunakan adalah metode penelitian deskriptif kualitatif. Melaui pendkatan ini diharapkan peneliti mampu menghasilkan data yang bersifat deskriptif untuk mengungkap proses terjadinya di lapangan.

Menurut Andi Prastowo (2011: 24) metode penelitian kualitatif adalah metode (jalan) penelitian yang sistematis yang digunakan untuk mengkaji atau meneliti suatu objek pada latar alamiah tanpa ada manipulasi di dalamnya dan tanpa ada pengujian hipotesis, dengan metodemetode yang alamiah ketika hasil penelitian yang diharapkan bukanlah generalisasi berdasarkan ukuran-ukuran kuantitas, namun makna (segi kualitas) dari fenomena yang diamati.

Penelitian ini menggunakan pendekatan kualitatif karena peneliti bermaksud mendeskripsikan, menguraikan dan menggambarkan secara lisan maupun tertulis mengenai proses pendampingan yang dilaksanakan oleh Rumah Perlindungan Sosial Anak (RPSA) di Kota Makassar. Metode penelitian yang digunakan oleh peneliti yakni deskriptif kualitatif. Deskriptif kualitatif yakni data yang dikumpulkan adalah berupa kata-kata, gambar dan bukan angka-angka (Nana Syaodih Sukmadinata, 2010:11). Dalam penelitian ini diharapkan akan diketahui mengenai proses pelaksanaan pendampingan di Rumah Perlindungan Sosial Anak (RPSA) Di Kota Makassar.

Penelitian ini dilaksanakan di Rumah Perlindungan Sosial Anak (RPSA) di Kota Makassar terletak di jalan Langgau N0.68 Kelurahan La'latang Kecamatan Tallo Kota Makassar. Rumah Perlindungan Sosial Anak (RPSA) di Kota Makassar merupakan salah satu lembaga sosial yang mengurusi mengenai anak jalanan. Lokasi penelitian yang ditetapkan dalam penelitian ini yaitu peranan pendampingan sosial yang dilaksanakan terhadap anak jalanan, peneliti juga melakukan penelitian mengenai faktor pendorong dan faktor penghambat dari kegiatan pendampingan, serta dampak pendampingan sosial terhadap anak jalanan di Rumah Pelayanan Sosial Anak (RPSA) di Kota Makassar
Sesuai dengan judul penelitian yakni Pendampingan Sosial Terhadap Anak Jalanan Kota Makassar di fokuskan pada anak korban tindak kekerasan dan eksploitasi yang didampingi oleh pendamping sosioal. Pendampingan yang di lakukan oleh Rumah Perlindungan Sosial Anak (RPSA).

Hanya manusia sebagai instrumen dapat memahami makna interaksi antar manusia, membaca gerak muka, serta menyelami perasaan dan nilai yang terkandung dalam ucapan atau perbuatan responden (Andi Prastowo, 2011:43). Peneliti kualitatif sebagai human instrument, berfungsi menetapkan fokus penelitian, memilih informan sebagai sumber data, melakukan pengumpulan data, menilai kualitas data, analisis data, menafsirkan data dan membuat kesimpulan atas temuannya (Sugiyono, 2012:306). Dalam penelitian kualitatif, yang menjadi instrumen atau alat penilitian adalah peneliti itu sendiri.

Dalam penelitian ini, instrumen yang akan digunakan dalam penelitian pendampingan yang dilaksanakan di Rumah Perlindungan Sosial Anak (RPSA) di Kota Makassar adalah peneliti sendiri yang dibantu pedoman dengan wawancara, pedoman observasi dan pedoman dokumentasi terstruktur yang dibuat sendiri oleh peneliti.

Dalam penelitian ini menggunakan pendekatan kualitatif dengan analisa data dilakukan bersamaan dengan pengumpulan data. Pengumpulan data penelitian kualititatif yang menjadi instrumen atau alat penelitian adalah peneliti itu sendiri (Sugiyono, 2012: 59). Pengumpulan data yang digunakan adalah dengan menggunkakan pengamatan, wawancara dan dokumentasi.

Jenis dan sumber data menjadi: Data primer yaitu data yang bersumber dari hasil observasi dan hasil interview secara mendalam dengan informan. Dan Data sekunder yaitu data yang di peroleh dari bahan kepustakaan dan berbagai referensi, misalnya buku-buku, majalah ilmiah, hasil penelitian, materi dari situs internet dan sumber bacaan lainnya yang terkait dengan permasalahan yang diteliti.

Setelah semua data terkumpul, data akan dianalisis menggunkan teknik analisis data kualitatif. Analisis data kualitatif yaitu upaya yang dilakukan dengan jalan bekerja dengan data, mengorganisasikan data, memilih data untuk dikelola, mencari dan menemukan pola, menemukan apa yang penting dan apa yang 
dipelajari dan memutuskan apa yang diceritakan pada orang lain (Moleong, 2005: 248).

Menurut pendapat Milles and Huberman (dalam Sugiyono, 2012:337), mengemukakan bahwa aktivitas dalam analisis pengumpulan data kualitatif dilakukan secara interaktif dan berlangsung secara terus menerus sampai tuntas, sehingga datanya sudah jenuh. Aktivitas dalam analisis data, yaitu data reduction, data display, dan conclusing drawing.

Agar hasil penelitian benar-benar dapat dipertanggungjawabkan, maka diperlukan adanya keabsahan data dari data yang sudah diperoleh. Triangulasi adalah teknik pemeriksaan keabsahan data yang memanfaatkan sesuatu yang lain. Menurut Moleong (2007: 330-331), triangulasi sumber data adalah peneliti mengutamakan checkrecheck, cross-recheck antar sumber informasi satu dengan lainnya. Peneliti dapat merececk data temuannya dengan cara membandingkan berbagai sumber, metode, penyidik, atau teori.

\section{HASIL DAN PEMBAHASAN}

Profil Dinas Sosial Kota Makassar

a) Sejarah Singkat Dinas Sosial Kota Makassar

Dinas Sosial Kota Makassar yang sebelumnya adalah Kantor Departemen Sosial Kota Makassar didirikan berdasarkan Keputusan Presiden No. 44 Tahun 1974 Tentangpokokpokok Organisasi Departemen dan keputusan PresidenN0. 45 tahun 1974 tentang Susunan Organisasi Departemenbeserta lampiranlampirannya sebagaimana beberapa kali dirubah, terakhir dengan Keputusan Presiden No. 49 Tahun1983.

Khusus di Indonesia Timur didirikan Departemen Sosial Daerah Sulawesi Selatan yang kemudian berubah menjadi Jawatan Sosial lalu dirubah lagi menjadi kantor Departemen Sosial berdasarkan keputusan Menteri Sosial RI No. 16 Tahun1984 tentang Organisasi dan Tata Kerja Kantor Departemen Sosial di Provinsi maupun di Kabupaten/Kota madya. Dan akhirnya menjadi Dinas Sosial Kota Makassar pada tanggal10 April 2000 yang ditandai dengan pengangkatan dan pelantikan Kepala Dinas Sosial Kota Makassar berdasarkan Keputusan WaliKota Makassar, Nomor: 821.22:24.2000 tanggal 8 Maret 2000.

\section{B. Gambaran Umum Lembaga Sosial Pembinaan Anak Jalanan di Kota Makassar.}

Upaya pemerintah kota dalam mengatasi anak jalanan diKota Makassar harus berhadapan dengan lingkungan masyarakat dan berbagai unsur-unsur penopangnya salah satunya Lembaga sosial. Dukungan peraturan perundang-undangan serta kebijakan penanggulangan anak maupun pembinaan anak jalanan yang dilaksakan oleh pemerintah kota masih harus disinergikan dengan kondisi sosial kemasyarakatan di daerah ini.

Berbagai faktor yang selama ini dianggap sebagai persoalan klasik yang memunculkan anak jalanan memerlukan perhatian serius sehingga efektifitas dari kegiatan yang dilaksakan oleh pemerintah kota dapat berjalan sesuai dengan yang diharapkan. Secara teoritis, fokus utama pembangunan kesejahteraan sosial adalah pada perlindungan sosial. Oleh karena itu, model pertolongan terhadap anak jalanan bukan sekedar menghapus anak-anakdari jalanan. Melainkan harus bisa meningkatkan kualitas hidupmereka melalui lembaga sosial yang khusus membina anak jalanandi kota Makassar.

a. Rumah Perlindungan Sosial Anak (RPSA) Turikale Makassar

Rumah Perlindungan Sosial Anak (RPSA) merupakan layanan bagi anak yang memerlukan perlindungan khusus. Perlindungan anak merupakan segala bentuk kegiatan untuk menjamin dan melindungi anak dan hak-haknya agar dapat hidup, tumbuh, berkembang dan berpartisipasi secara optimal sesuai harkat dan martabat kemanusiaan serta mendapatkan perlindungan dari tindak kekerasan dan deskriminasi.

Dalam hal ini RPSA bertugas memberikan penanganan sistematis, terstruktur, terencana, dan terintegrasi dengan mengedepankan perspektif korban dan kepentingan terbaik anak. Dalam fungsinya, RPSA sebagai temporary shelter dan Protection Home, memberikan perlindungan, pemulihan, rehabilitasi, advokasi, reunifikasi dan reintegrasi bagi anak yang mengalami tindak kekerasan dan perlakuan salah atau yang memerlukan perlindungan khusus, sehingga kelangsungan hidup, tumbuh kembang dan partisipasi anak dapat terjamin. Seperti yang diungkapkan oleh pendamping Ibu "ATI" selaku pengelola Rumah Perlindungan Sosial Anak (RPSA) Turikale Kota Makassar:

"Kebaradaan anak yang memproleh pelayanan di RPSA, memberi gambaran bahwa anak-anak tersebut telah memproleh perlindungan, pemulihan, rehabilitasi, advokasi, 
reunifikasi dan reintegrasi, yang pada akhirnya ditujukan agar anak dapat hidup sesuai dengan anak normal pada umumnya" (Wawancara, 18/04/2018)

Pendapat di atas diperkuat dengan penjelasan Ibu "Hasnah Hapsari" selaku Kepala RPSA sebagai berikut:

"Kasus-kasus pada anak yang memerlukan perlindungan khusus tersebut, sumber permasalahannya bermuara dalam keluarga. Dalam hal ini kami tekankan bahwa orang tua dan keluarga memiliki kewajiban dan tanggung jawab untuk mengasuh dan mendidik serta melindungi perkembangan anak, tepatnya bahwa anak selalu bersama orang tua atau keluarga sebagai tempat yang pertama dalam menjalankan kehidupannya sekalipun anak telah memproleh pelayanan dari RPSA" (Wawancara, 20/04/2018).

b) Pelayanan di Protection Home, melalui proses rencana intervensi, pelaksanaan intervensi, evaluasi dan terminasi, yang selanjutnya dilakukan reunifikasi dan reintegrasi serta referal meliputi:

1) Reunifikasi adalah mempertemukan dan menyatukan klien kepada orang tua, anggota keluarga, atau kerabat, untuk memberikan perlindungan dan pemenuhan kebutuhan. Keluarga asli adalah target pertama dalam reunifikasi. Jika tidak memungkinkan maka dialihkan oleh kerabatnya dan bentuk-bentuk alternatif pengasuhan lainnya yang berbasis keluarga, agar dapat menyatukan keluarga atau kerabat serta bentuk alternatif pengasuhan lainnya berbasis keluarga sehingga dapat tumbuh kembang secara wajar.

2) Reintegrasi adalah penyatuan kembali klien dengan masyarakat yang dapat memberikan perlindungan dan kebutuhan kebutuhan bagi klien, termasuk sistem kekerabatan, lembaga pendidikan, kesejahteraan sosial, dan seterusnya agar anak dapat tumbuh dan kembali hidup dalam lindungan masyarakat secara wajar.

3) Referal/Rujukan adalah kegiatan pengalihan pelayanan anak ke lembaga layanan lanjutan lain, yang dibutuhkan dalam penanganan dan pemenuhan hak anak, kerana pelayanan yang dibutuhkan tidak tersedia atau sudah selesai di RPSA. Proses rujukan dilakukan oleh petugas dengan menyiapkan oleh form yang tersedia, membawa surat tugas, alat dokumentasi, dan akomodasi.

\section{Pembahasan}

1. Tahapan Pendampingan Anak Jalanan di Rumah Perlindungan Sosial Anak (RPSA) Turikale Kota Makasaar

Hasil penelitian menunjukan bahwa mekanisme dan tahapan pendampingan anak jalanan di Rumah Perlindungan Sosial Anak (RPSA) Turikale Kota Makasar sudah berjalan sejak tahun 2009. Program pendampingan murni berasal dari Rumah Perlindungan Sosial Anak (RPSA) Turikale Kota Makasar. Tahapan dalam pendampingan secara umum meliputi tahapan persiapan, tahap assement, tahap perencanaan alternatif program, tahap peformulasian rencana aksi, tahap pelaksanaan, tahap evaluasi, tahap terminasi. Pendampingan yang dilaksanakan oleh Rumah Perlindungan Sosial Anak (RPSA) Turikale Kota Makasar sesuai dengan tahapantahapan yang sudah seharusnya dilakukan agar pendampingan dapat berjalan dengan baik dan tepat.Tahapan pendampingan di Rumah Perlindungan Sosial Anak (RPSA) Turikale Kota Makasar yakni:

a) Perencanaan atau persiapan

Sebelum pendampingan dibutuhkan perencanaan yang baik agar tujuan dari pendampingan dapat tercapai. Sebelum dimulai ada beberapa halyang harus dipersiapkan oleh pendamping. Pendamping menyiapkan materi, mentor untuk belajar yakni pendamping sendiri dan peserta didik yakni anak jalanan. Seperti yang diungkapkan oleh pendamping yakni "WIDYA" sebagai berikut:

"Kegiatan pendampingan yang saya lakukan berupa kegiatan belajar dan bermain, anak-anak dapat belajar tentang kesulitan yang mereka hadapi disekolah. Satu anak dengan anak yang lain berbeda-beda. Tugas pendamping juga menjadi pendengar mengenai kesulitan dan permasalahan anak jalanan yang kemudian nanti mencarikan jalan keluar atau mengkomunikasikan dengan orang tua. Selain itu juga anak jalanan harus siap ketika akan belajar" (Wawancara, 21/04/2018)

Hal senada juga diungkapkan oleh Ibu "ATI" selaku pengelola Rumah Perlindungan Sosial Anak (RPSA) Turikale Kota Makassar:

"Biasanya sebelum melaksanakan pendampingan yang harus dipersiapakan adalah alat dan bahan (materi) apa yang akan kita berikan ke anak" (Wawancara, 23/04/2018).

Materi yang diberikan oleh pendamping disesuaikan dengan minat anak jalanan. Anak jalanan tidak hanya membutuhkan pengetahuan 
namun juga ketrampilanseperti yang diutarakan olek "ATI" bahwa:

"Pendampingan juga mengikuti maunya anak, contohnya IC memberikan keterampilan kepada anak dampingannya tentang keterampilan bengkel atauotomotif karena anakanak menginginkan belajar hal itu, saya juga tidak jarang memberikan materi kerajinan tangan karena anak-anak menginginkan belajar kerajinan tangan" (Wawancara, 25/04/2018)

Selain itu persiapan lainnya yang harus dipersiapkan sebelum pendamping melaksanakan pendampingan yakni dengan menyiapakan tempat. Tempat merupakan sarana dan faktor yang sangat penting agar anak mau untuk mengikuti kegiatan. Tempat yang digunakan untuk pendampingan menggunakan salah satu rumah anak jalanan. Hal tersebut agar hubungan pendamping dengan orang tua anak jalanan bisa terjalin dengan baik. Struktur sebagi sesuatu yang bersifat eksternal bagi tindakan manusia, sebagai sumber yang mengekang kekuasaan subjek yang disusun secara mandiri. sebagaimana yang dikonseptualisasikan dalam pemikiran strukturalis dan post-strukturalis. Dalam hal ini struktur secara khas dianggap bukan sebagai pembuat pola kehadiran seorang melainkan sebagi titik simpang antara kehadiran dan ketidak hadiran. Kode-kode dasar harus disimpulkan dari manifestasi-manifestasi yang merekat (Giddens, 2011:20). Perkenalan dan kontak sosial juga dilakukan sebelum melaksanakan pendampingan hal ini agar nantinya saat pelaksanaaan pendampingan anak binaan dapat fokus, dan terkendali.

Dari hasil wawancara peneliti dapat menyimpulkan bahwa persiapan atau perencanaan yang dilakukan oleh pendamping sudah cukup baik karena melihat dari kebutuhan dan minat anak binaan.

b) Pelaksanaan

1) Pendampingan dan Sharing Orang Tua Binaan

Kegiatan ini dilaksanakan oleh Rumah Perlindungan sosial Anak (RPSA) Turikale Kota Makassar selama dua kali dalam sebulan. Kegiatan ini biasanya dilaksanakan pada awal dan akhir bulan. Hal tersebut seperti yang diungkapkan oleh "IBNU CHALDUN" selaku pendamping sebagai berikut:

"Dalam sebulan dua kali biasanya RPSA mengadakan kunjungan ke keluarga anak jalanan. Adanya kegiatan ini tujuan utamanya agar orangtua dapat mengkomunikasikan apa yang menjadi permasalahan untuk anaknya. Jadi bukan hanya dari RPSAyang membenahi si anak tapi orang tua juga mempunyai perananyang besar dalam membantu anak agar dapat hidup dengan lebihbaik" (Wawancara, 25/04/2018)

Berdasarkan pengamatan peneliti para orang tua dan anak binaan sangat antusias terhadap kegiatan ini, di sesi sharing banyaknya sharing yang dikemukakan oleh para orang tua. Tujuan dari kegiatan ini agar anak danorang tua dapat saling mendukung anak untuk hidup secara lebih baik, danterjalin hubungan yang lebih baik antara anak dan orang tua. Selain itu juga terbina komunikasi yang baik antara anak binaaan, orang tua binaan dan Rumah Perlindungan Sosial Anak (RPSA) Turikale Makassar. Seperti yang diungkapkan oleh Ibu "ATI" selaku pengelola sebagai berikut ini:

"bertujuan, agar adanya komunikasi yang baik antara anak jalanan, RPSA dan juga orang tua, silahturahmi lebih tepatnya" (Wawancara, 30/04/2018).

Pendapat di atas diperkuat dengan penjelasan Ibu "HASNAH HAPSARI" selaku Kepala RPSA sebagai berikut:

"Tujuannya memperkuat tali silahturahmi dengan orang tua, dananak tetap semangat mengikuti kegiatan pendampingan" (Wawancara, 03/05/2018).

Dari wawancara yang dilakukan dapat disimpulkan pendampingan dan Sharing orangtua anak Binaan dilaksanakan secara rutin untuk penyampian informasi, mengkomunikasikan permasalahan yang harus diketahui orangtua, sharing antara orangtua dan anak serta silahturahmi antara RPSA, anak binaan dan orang tua.

2) Pelatihan Keterampilan

Pelatihan awalnya banyak yang berjalan sesuai jadwal namun karena adanya kekurangan tenaga maka untuk saat ini yang masih berjalan adalah pelatihan kerajinan tangan. Seperti yang diungkapkan oleh "WIDYA" berikut ini:

"ada pelatihan keterampilan seperti memasak tapi untuk beberapa waktu dihentikan dulu, kita lagi kekurangan tenaga pendamping" (Wawancara, 07/05/2018)

Pelatihan keterampilan tanagn rutin dilaksanakan 2 kali seminggu di Rumah Perlindungan Sosial Anak (RPSA) Kota Makassar. Anak-anak binaan yang datang dariberbagai lokasi yang ada di Kota Makassar dan tinggal sementara di RPSA. Kegiatan ini lumayan diminatioleh anak-anak binaan. Anak- 
anak jalanan yang sebagian belum bisa membuat kerajinan tanagn. Maka pelatihan ini berguna untuk melatih mereka agar memiliki keterampilan dasar dalam membuat kerajinan tangan. Mayoritas anak yang berminat dipelatihan ini adalah anak-anak binaan sekitar RPSA. Seperti yang diungkapkan oleh "ATI" selaku pengelola berikut ini:

"Anak-anak membuat kerajinan tangan pada hari rabu dan kamis, ini diikutianak perempuan maupun laki-laki. Anak-anak yang dari jalanan kebanyakan tidak bisa membuat kerajinan tangan. Mereka antusias sekali karena hasil kerajinan tangan juga dibawa pulang" (Wawancara, 08/05/2018)

Hal itu diperkuat oleh "SUKRI" selaku anak dampingan RPSA seperti berikut ini:

"Saya paling suka kalau buat kerajinan tangan. Kita diajari buat kerajinan ini dan itu. Walaupun agak sulit tapi menyenangkan. Selain itu juga bisa ketemu sama teman-teman lainnya" (Wawancara, 11/05/2018).

Dari hasil wawancara yang dilakukan dapat disimpulkan bahwa pelatihan yang berjalan saat ini tinggal satu yaitu membuat kerajinan tangan. Kegiatan tersebut diminati oleh anak jalanan.

3) Pendampingan Kesehatan

Selain sharing anak dengan pendamping tetang masalah yang mereka hadapi, pendamping juga mendengarkan keluhan kesehatan dari anak binaan. Pendamping juga mengamati dan memantau sendiri. Apabila ada anak yang sakit dibawa ke puskesmas. Seperti yang diungkapkan oleh Ibu "ATI" berikut ini:

"Kita perhatikan anak-anak termasuk kesehatannya juga,kayak dulu ada yang mengeluh sakit dikira sakit biasa ternyata paruparu, ya kita dampingi sampai sembuh kembali. Selainitu juga kalau misalnya ada anak yang curhat, kita dengarkan dankita bantu, jika kita masih bisa mengatasi sendiri tapi kalaumemerlukan psikolog kita menggunakan psikolog. Tapi bagaimanapun anak lebih terbuka kalo sama kita (pendamping) karenasudah tidak malu lagi" (Wawancara, 14/05/2018).

Berdasarkan hasil wawancara yang dilakukan di atas, dapat disimpulkan bahwa kesehatan anak jalanan sangat diperhatikan oleh Rumah Perlindungan sosial Anak (RPSA) Turikale Kota Makassar yang bekerjasama dengan puskesmasdan psikolog.

4) Home Visit
Tujuan dari diadakan home visit agar anak-anak binaan tetap dekat dan rutin mengikuti kegiatan yang dilaksanakan oleh Rumah Perlindungan sosial Anak (RPSA) Turikale Kota Makassar. Seperti yang dijelaskan oleh Ibu "ATI" selaku pengelola, berikut ini:

"Home visit biasanya dilakukan oleh Ibu "HASNAH HAPSARI" kegiatan ini bisa dilakukan kapan saja disaat ada waktu luang, tujuanya ya biarterjaga aja silahturahminya" (Wawancara, 15/05/2018).

Hal itu diperkuat dengan penjelasan dari bapak "HASNAH HAPSARI" selaku Kepala RPSA sebagai berikut:

"Home visit, kunjungan yang bersifat santai biar anak-anak danorang tua tetap dekat dengan RPSA" (Wawancara, 15/05/2018).

Dari wawancara diatas home visit dilakukan kapan saja olehpendamping disaat ada waktu luang dan mempunyai tujuan untuk menjaga hubungan baik antara anak, orang tua dan RPSA.

c) Evaluasi

Setiap selesai kegiatan pendampingan maka diadakan evaluasi oleh pendamping. Evaluasi dapat dilakukan dengan cara pendamping mereview kembali materi yang disampaikan dan sharing tentang kegiatan berikutnya yang ingin anak jalanan lakukan. Selain itu evaluasi yang dilakukan antar pendamping juga dilakukan saat rapat mingguan. Setiap pendamping melaporkan kegiatan pendampingannya, apabila ada masalah yang perlu didiskusikan yang maka diselesaikan di rapat mingguan. sebagaimana diungkapkan oleh Ibu "ATI" yaitu sebagai berikut"

"Kalau untuk evaluasi saya biasanya dengan cara mengulang kembali bahan dan alat saat kegiatan yang telah dilaksanakan, agaranakanak juga berinisiatif untuk antusias. Untuk masalah yangsusah solusinya atau berat biasanya kita sharingkan di rapat mingguan. Di dalam rapat mingguan kan melaporkan pendampingannya masing-masing" (Wawancara, 16/05/2018)

Hal senada juga dituturkan oleh "IBNU CHALDUN" mengenai evaluasipendampingan, yakni:

"Dalam pengevaluasian setelah kegiatan pendampingan saya biasanya mereview kembali apa yang sudah didapatkan hari ini dan sharing apa yang akan dipelajari pertemuan berikutnya jugamenanyakan apakah ada masalah dengan anak-anak atau tidak, jikaada yang saya sebagai 
pendamping akan mengkonsultasikan dengan orang tua" (Wawancara, 25/04/2018)

Dari hasil wawancara dapat disimpulkan bahwa menggunakan teknik mereview kegiatan yang sudah dilaksanakan. Evaluasi yang diadakan di rapat mingguan juga sangat bagus untuk memperbaiki kelemahan-kelemahan yangada di pendampingan. Hal tersebut dapat menunjukan bahwa evaluasi sangat penting dilakukan, karena dengan dengan dilakukannya evaluasi dapat mengetahui dan mengukur pendampingan yang telah disampaikan oleh pendamping berhasil atau tidak ataupun mengetahui perubahan anak binaan.

2. Faktor Pendukung dan Hambatan yang Terjadi dari Pendampingan di Rumah Perlindungan Sosial Anak (RPSA) Turikale Kota Makassar

Dalam pendampingan yang diadakan oleh Rumah Perlindungan Sosial Anak (RPSA) Kota Makassar tentu ada faktor pendukung dan penghambat dalam penyelenggaraanya yang akan diuraikan sebagaimana berikut ini:

a) Faktor Pendukung

Dalam pendampingan yang dilaksanakan RPSA dalam pelaksanaanya terdapat faktor pendukung, yakni:

1) Kesabaran Pendamping

Dalam observasi yang dilakukan oleh peneliti pada setiap pendampingan di Rumah Perlindungan Sosial Anak (RPSA) Kota Makassar hubungan yang terlihat antara pendamping dengan anak jalanan yang menjadi binaan terjalin dengan baik, bahkan hubungan dengan keluarga anak jalananpun terjalin amat baik. Selama pendampingan beberapa anak terlihat asyik sendiri ataupun hanya menulis coretan-coretan dibuku tulis, ada anak yang gampang putus asa ketika susah mengerjakan tugasnya namun pendamping mendampingi anak dengan sabar, ramah dan disiplin. Ketika anak-anak benar-benar terlalu ramai pendamping kembali mengingatkan untuk fokus pada materi belajar.

Hal tersebut diungkapkan oleh "FARAH" selaku anak jalanan yang mengikuti pendampingan sebagai berikut:

"ibu "WIDYA" itu orangnya sabar kalo kita lagi belajar bersama. Semua dijelaskan satu persatu yang tidak bisa" (Wawancara, 18/04/2018)

Diperkuat dengan pernyataan dari ibu "ATI" selaku pengelola dan pendamping yakni:
"Saya selaku pendamping dalam membimbing mereka mestisabar agar mereka nyaman dan antusias. Saya ingin mereka dapat hidup secara mandiri." (Wawancara, 18/04/2018)

Hubungan yang terjalin dengan baik antara anak jalanan yang menjadi binaan dengan pendamping dilihat dari anak yang sangat menghormati pendamping. Dualitas struktur selalu merupakan dasar utama berkesinambungan dalam reproduksi sosial dalam ruang dan waktu. Pada gilirannya hal ini mensyaratkan monitiring reflektif agen-agen dan sebagaimana yang ada di dalam aktivitas sosial sehari-hari (Dr. Abdul Malik Iskandar, M.Si, 2017:46). Hubungan yang baik tidak hanya terjadi antara anak binaan dengan pendamping namun antara orang tua dan pendamping juga terjalin sangat baik. Namun dengan tidak mengurangi ketegasan pendamping untuk mendisiplinkan anak jalanan agar dapat hidup mandiri dan keluar darijalanan.

\section{2) Hubungan kelembagaan atau kemitraan}

Hubungan kelembagaan atau kemitraan antara RPSA denganpihak lain terjalin baik. Hubungan kemitraan RPSA terjalin dengankementrian sosial Republik Indonesia sebagai lembaga pusat yang menaungi kegiatan sosial, kementrian pendidikan dan kebudayaan, dinas sosial Kota Makassar, dinas pendidikan pemuda dan olahraga. Rumah Perlindungan Sosial Anak (RPSA) Kota Makassar sudahberdiri dari tahun 2009 dengan waktu yang lama tersebut menjalin hubungan kelembagaan yang baik dengan Dinas Sosial.

Hal tersebut diungkapkan oleh Ibu "HASNAH HAPSARI" selaku Kepala RPSA bahwa:

"Yang menjadi pendukung bagi kami yakni adanya kegiatan tahunan, program kemitraan dan tim yang tangguh" (Wawancara, 20/04/2018).

Adanya hubungan kelembagaan dan kemitraan dengan pihak lainbertujuan untuk memperkenalkan RPSA kepada masyarakat sebagai salah satu lembaga sosial yang menangani anak jalanan dan turut berpartisipasi dalam memnyelenggarakan program-program yanga ada di Rumah Perlindungan sosial Anak (RPSA) Kota Makassar.

3) Partisipasi anak jalanan

Partisipasi anak jalanan yang cukup tinggi dalam mengikuti kegiatan pendampingan, karena anak jalanan (anak binaan) dapat 
menambah pengetahuan, ketrampilan dan wawasan serta menambah manfaat. Sepertiyang dilihat peneliti saat pendampingan untuk anakanak jalanan di Rumah Perlindungan Sosial Anak (RPSA) Kota Makassar. Anak-anak jalanan yang bersekolah maupun tidak bersekolah sangat antusias dalam memperhatikan materi pelajaran yang diberikan oleh pendamping. Hal tersebut seperti diungkapkan oleh "FARAH" seperti berikut:

"Senang bisa belajar, saya belajar pelajaran-pelajaran kelas 4SD (sekolah dasar). Saya sekolah cuman sampai kelas 4 SD" (Wawancara, 18/04/2018).

Hal senada juga diungkapkan oleh "SOFYAN FAJAR" sebagai berikut:

"sangat bermanfaatlah mbak, kan bisa buat ngerjain PR dari sekolah terus belajar bareng teman-teman juga" (Wawancara, 26/04/2018).

Dari uraian di atas dapat di simpulkan bahwa faktor yang mendukung kegiatan pendampingan yakni meliputi kesabaran pendamping dalam memberian pengetahuan maupun keterampilan, hubungan kemitraan dan partisipasi anak jalanan.

b) Faktor Penghambat

Dalam kegiatan pendampingan yang diadakan untuk anak jalanan di Rumah Perlindungan sosial Anak (RPSA) Kota Makassar di dalam pelaksanaanya tentuada faktor yang menghambat kegiatan pendampingan. Berdasar kanpengamatan peneliti yakni sebagai berikut:

1) Kekurangan Tenaga Pendamping

Tenaga pendamping yang ada di RPSA kurang seimbangdengan adanya banyak anak jalanan yang menjadi binaan. Faktor yang menjadi penghambat tersebut juga diungkapkan oleh Ibu "HASNAH HAPSARI" sebagai berikut:

"Penghambat kegiatan pendampingan sejauh ini waktu pendampingan yang hanya seminggu dua kali, anak jalanan yang minim support dari orangtua dan variasi kegiatan yang sedikit" (Wawancara, 11/05/2018).

Pendapat Ibu "HASNAH HAPSARI" diperkuat oleh pendapat dari "IBNU CHALDUN" yang menjelaskan bahwa:

"Hambatan yang dihadapi RPSA untuk saat ini kurangnya tenaga pendamping, dan kurangnya support dari orang tua sih" (Wawancara, 11/05/2018).
Berdasarkan pengamatan peneliti semua yang sudah direncanakan sudah sangat baik namun dalam pelaksanaan terkendala pada jumlah pendamping yang tidak sebanding dengan jumlah anak binaan. Jadi satu pendamping, mendampingi belasan anak jalanan mengakibatkan kurang terkontrolnya situasi pendampingan. Konsentrasi anak juga terpecah karenaketika pendampingan memberikan penjelasan materi kepada salah satu anakbinaan, anak binaan yang lain ikut memperhatikan tidak memperhatikan tugasnya sendiri.

2) Motivasi Anak jalanan

Anak jalanan yang mengikuti pendampingan terkadang banyak dandilain waktu sedikit, hal ini disebabkan karena motivasi anak jalanan naik turun.

Seperti yang di ungkapkan oleh "WIDYA" yakni menyatakan:

"Anak-anak yang motivasinya kurang, kurangnya SDM dan anakyang moodnya naik turun" (Wawancara, 02/05/2018)

Pendapat mbak "WIDYA" diperkuat oleh penjelasan dari mbak "IBNU CHALDUN" sebagai berikut ini:

"Kalo untuk saya hambatan yang terjadi mood anak yang kadang malas waktu pendampingan yang tidak teratur dan kurangnya SDM" (Wawancara, 02/05/2018).

Mood anak binaan menyebabkan kehadiran anak binaan di kegiatan pendampingan naik turun. Mood anak jalanan yang sangat labil dan memerlukan motivasi secara intens.

\section{3) Minim Support}

Faktor penghambat ini muncul dari anak jalanan, anak-anak binaanyang semangat belajarnya naik turun tapi kurang mendapat perhatian dariorang tuanya. Rendahnya dukungan dari orang tua untuk mengikuti pendampingan membuat anak semaunya dalam mengkiuti pendampingan.

Seperti yang diungkapkan oleh "IBNU CHALDUN" berikut ini:

"Kegiatanya biasanya molor karena anak-anak banyak yang terlambat." Sebenarnya peran orang tua harus terlibat disini untuk memotivasi anaknya" (Wawancara, 02/05/2018).

Hal tersebut diperkuat dengan penjelasan "SYAMSUL BAHRI" selaku anak binaan sebagai berikut:

"Harus meluangkan waktu untuk belajar meskipun kadang malas-malas, ya 
menyemangati diri sendiri" (Wawancara, 26/04/2018).

Hal tersebut diperkuat dengan pendapat "SUKRI" selaku anak binaan seperti berikut ini:

"Kadang semangat sekali untuk belajar sama-sama tapi kadang kalo pasmalas, ya malas" (Wawancara, 26/04/2018).

Peran orang tua dalam memotivasi anaknya akan berpengaruh besar terhadap semangat anak. Agar anak mau melakukan perubahan pada dirinya. Maka pendampingan juga ditujukan kepada orang tua. Orang tua anak-anak binaan juga dapat memotivasi anaknya agar mampu hidup lebih maju.

Berdasarkan pengamatan peneliti selama mengikuti kegiatan pendampingan, anak jalan kurang fokus dalam mengikuti pendampingan karena adanya orang tua mereka yang lebih menginginkan anaknya bekerja membantunya. Sementara itu mayoritas pekerjaan dari orang tua adalah mengamen.

3. Dampak Pendampingan Anak Jalanan di Rumah Perlindungan Sosial Anak (RPSA) Turikale Kota Makasaar Keberadaan anak jalanan sudah lazim kelihatan pada kota-kota besar di Indonesia. Kepekaan masyarakat kepada mereka nampaknya tidak begitu tajam. Padahal Anak merupakan karunia Ilahi dan amanah yang dalam dirinya melekat harkat dan martabat sebagai manusia yang harus dijunjung tinggi. Hak asasi anak merupakan bagian dari hak asasi manusia sebagaimana yang tercantum dalam UUD 1945, UU No.39 tahun 1999 tentang Hak Asasi Manusia, dan Keputusan Presiden Republik Indonesia Nomor 36 tahun 1990 tentang pengesahan Convention on the right of the child (Konvensi tentang hak-hak anak). Tak bisa dipungkiri bahwa persoalan anak jalanan belakangan telah menjadi fenomena sosial dalam kehidupan kota besar. Kehadiran mereka seringkali dianggap sebagai cermin kemiskinan kota. Di mata sebagian anggota masyarakat, keberadaan anak jalanan hingga kini masih dianggap sebagai "limbah" kota yang harus disingkirkan (Mangkoesapoetra, 2005). Eksistensi mereka dirasakan menggangu kenyamanan dan keamanan berlalu lintas dan sering kali dituduh melakukan tindakan kriminal, seperti mencopet atau menodong. Ditambah lagi adanya kecurigaan bahwa anak jalanan dikendalikan oleh sindikat tertentu membuat keberadaan anak jalanan di kota-kota besar menjadi duri yang tidak menyenangkan.
Seseorang bisa dikatakan anak jalanan bila berumur dibawah 18 tahun yang menggunakan jalanan sebagai tempat mencari nafkah dan berada di jalan lebih dari 6 jam sehari. Ada beberapa tipe anak jalanan, yaitu: a) Anak jalanan yang masih memiliki orang tua dan tinggal dengan orang tua. b) Anak jalanan yang masih memiliki orang tua tapi tidak tinggal dengan orang tua c) Anak jalanan yang sudah tidak memiliki orang tua tapi tinggal dengan keluarga d) Anak jalanan yang sudah tidak memiliki orang tua dan tidak tinggal dengan keluarga. Berbagai penelitian menunjukkan bahwa anak-anak yang turun menjadi anak jalanan sebagian besar berpendidikan rendah (W. Nurhadjatmo, 2004). Anak jalanan umumnya berasal dari keluarga yang pekerjaanya berat dan ekonominya lemah. Anak jalanan tumbuh dan berkembang dengan latar belakang kehidupan jalanan dan akrab dengan kemiskinan, penganiayaan, dan hilangnya kasih sayang dari orang tua, saudara maupun temantemanya, sehingga memberatkan jiwa dan membuatnya berprilaku negatif. Masalah sosial anak jalanan berkaitan dengan ketidakmampuan anak memperolah haknya, sebagaimana diatur oleh konvensi hak anak. Juga disebabkan kurangnya aksesibilitas anak, akibat berbagai keterbatasan sarana dan prasarana yang ada, baik di rumah dan di lingkungan sekitarnya untuk dapat bermain dan berkembang sesuai dengan masa pertumbuhannya. Selain itu, masalah sosial anak jalanan berkaitan pula dengan ketidakmampuan orang tua atau keluarga dalam memenuhi kebutuhan dasar anak.

Opini Giddens sesuai dengan pandangan awam tentang identitas, karena ia mengatakan bahwa Dampak pendampingan pada anak jalanan dapat mengatasi permasalahan belajar anak jalanan, anak menjadi terampil karena deberikan fasilitas keterampilan sesuai bakatnya, dapat merubah mind set (pola pikir) orang tua anak tersebut agar tidak mengulangi penyimpangan sosial terhadap anak dan mengharmonisasikan hubungan anak dan orang tua. Karena adanya proses pendampingan sehingga perilaku negatif anak tersebut dapat berkurang. Seperti yang di ungkap oleh, " MBAK WIDYA" selaku pendamping berikut ini: "Saya melihat perkembangan dengan adanya proses pendampingan terhadap anak jalanan yang kami lakukan itu berdampak positif disebabkan adanya perubahan perilaku antara 
anak dan orang tua, dari perilaku menyimpang menjadi lebih baik"(Wawancara, 17/05/2018) Pendapat di atas diperkuat dengan Ibu "HASNAH HAPSARI" selaku Kepala RPSA sebagai berikut:

"Setelah kami mengadakan monitoring dan evaluasi memang saya melihat adanya perubahan perilaku sikap antara orang tua dan anak "(Wawancara, 17/05/2018). Dari hasil wawancara yang dilakukan dapat disimpulkan bahwa dampak dari pendampingan sosial terhadap anak jalanan adanya perubahan perilaku sikap terhadap anak jalanan dan orang tua.

\section{SIMPULAN DAN SARAN}

Berdasarkan uraian dari hasil penelitian dan pembahasan yang telah dilakukan, maka dapat ditarik kesimpulan sebagai berikut:

1. Tahapan pendampingan yang dilaksanakan di Rumah Perlindungan Sosial Anak (RPSA) Turikale Makassar adalah Perencanaan meliputi pendampingan terhadap anak binaan, menentukan jadwal, materi dan metode serta permainan yang akan digunakan. Pelaksanaan pendampingan meliputi pendampingan belajar yang dilaksanakan oleh Rumah Perlindungan sosial Anak (RPSA) Turikale Kota Makassar, pendampingan dan Sharing Orang Tua binaan. Evaluasi yang dilakukan dengan melakukan Tanya jawab untuk mereview kembali materi yang sudah diajarkan.

2. Faktor Pendukung di Rumah Perlindungan Sosial Anak (RPSA) Turikale Makassar adalah: Kesabaran pendampingan dalam observasi yang dilakukan oleh pendamping di Rumah Perlindungan Sosial Anak (RPSA) Turikale Makassar hubungan yang terlihat antara pendamping dengan anak jalanan yang menjadi binaan terjalin dengan baik, Kelembagaan dan kemitraan Hubungan kelembagaan atau kemitraan antara rumah perlindungan dengan mitra terjalin baik, Hubungan kemitraan rumah perlindungan terjalin dengan Kementerian Sosial Republik Indonesia sebagai lembaga pusat yang menaungi kegiatan sosial, Partisipasi anakjalanan yang antusias dalam mengikuti kegiatan pendampingan hal ini disebabkan karena anak jalanan (anak binaan) dapat menambah pengetahuan, ketrampilan dan wawasan. Faktor penghambat Rumah Perlindungan Sosial Anak (RPSA) Turikale Makassar adalah: Kurangya tenaga pendamping yang ada dirumah perlindungansosial anak tidak seimbang dengan jumlah anak jalanan yang menjadi binaan dan kurangnya support dari orang tua, serta kurangnya motivasi anak jalanan yang mengikuti kegiatan pendampingan, dan kurangnya dukungan dari orangtua anak jalanan tersebut sehingga mempengaruhi anak dalam mengikuti pendampingan seperti terlambat karena kurangnya semangat, minimnya kesadaran, serta kurangnya motivasi orang tua terhadap anaknya.

3. Dampak pendampingan Anak Jalanan di Rumah Perlindungan Sosial Anak (RPSA) Turikale Kota Makassar adalah pendampingan pada anak jalanan dapat mengatasi permasalahan belajar anak jalanan, anak menjadi terampil karena deberikan fasilitas keterampilan sesuai bakatnya, dapat merubah mind set (pola pikir) orang tua anak tersebut agar tidak mengulangi penyimpangan sosial terhadap anak dan mengharmonisasikan hubungan anak dan orang tua. Karena adanya proses pendampingan sehingga perilaku negatif anak tersebut dapat berkurang

Berdasarkan kesimpulan dari hasil penelitian mengenai pendampingan anak jalanan di Rumah Perlindungan Sosial Anak (RPSA) Turikale Makassar yang telah diuraikan di atas, maka dapat diajukan beberapa saran yang bermanfaat bagi Rumah Perlindungan Sosial Anak (RPSA) Turikale Makassar, pendamping, dan anak binaan.

1. Bagi Rumah Perlindungan Anak (RPSA) Turikale Makassar yaitu: Hendaknya pendampingan dari segi psikologis lebih ditingkatkan, agar kualitas dan pribadi anak binaan lebih meningkat. Kurangnya SDM internal agar ditambah dengan mengajukan tambahan pekerjasosial ke Dinas Sosial atau Pemerintah

2. Bagi pendamping yaitu: Dalam pelaksanaan kegiatan pendampingan terhadap anak jalanan menggunakan metode penyampaian materi yang 
diselingi permainan agar anak-anak tidak merasa bosan.

3. Bagi anak binaan hendaknya mengikuti kegiatan dengan rajin dan antusias, serta secara aktif memotivasi dirinya sendiri agar selalu mengikuti kegiatan pendampingan dengan baik.

\section{SIMPULAN DAN SARAN}

Adi, (2003). Pemikiran-Pemikiran dalam Pembangunan Kesejahteraan Sosial. Seri Pemberdayaan Masyarakat. Jakarta: Fakultas Ekonomi Universitas Indonesia.

Ahmad, Rokhoul Alamin. 2010. Analisis Peran Pendamping Dalam Program Keluarga Harapan PKH) Pada Suku Dinas Sosial Jakarta Utara.

Albertina Nasri Lobo. 2008. Proses Pendampingan Wanita Pekerja Seks Komersial Dalam Upaya Pencegahan HIV/AIDS (Studi Kasus di Lokalisasi Tanjung Elmo Sentani oleh Perkumpulan Keluarga Berencana Papua). Diakses dari:http://lontar.ui.ac.id. Pada tanggal 07 November 2017 Jam 08.00 WIB

Ambar, Teguh Sulistiyani. 2004. Kemitraan dan Model-model Pemberdayaan. Yogyakarta. Gama Media

Andi, Prastowo. 2011. Metode Penelitian Kualitatif. Yogyakarta: Ar-Ruzz Media. Bagong, Suyanto. 2010. Masalah Sosial Anak. Jakarta: Prenada Media Group

Deddy, Mulyana. 2004. Metodologi Kualitatif. Bandung: PT Remaja Rosdakarya.

Departemen Sosial RI. 2007. Pendoman Pendamping Pada Rumah Perlindungan Dan Trauma Center. Jakarta: Depsos RI

Dinas sosial. 2010. Pengertian anak jalanan. Yogyakarta. Dinas sosial

Dinas sosial DIY. 2013. Laporan Hasil Pemuthakiran Data PMKS dan PSKS Tahun 2013. Yogyakarta: Dinas Sosial DIY

Edi, Suharto. 2011. Pekerjaan Sosial Di Indonesia Sejarah dan Dinamika Perkembangan. Yogyakarta: Samudra Biru

Fakih, Mansour. 2003.Menegakkan Keadilandan Kemanusiaan: Pegangan Untuk Membangun Gerakan HAM. Yogyakarta: Insist Press.

Giddens, Anthony. 2009. Problem Utama Dalam Teori Sosial, Menyangkut dengan Aksi, Struktur, dan Kontradiksi Dalam Anlisis Sosial atau dalam judul asli yang di unduh; Action, Structure, and Contracdition In Social Anlisis. Jakarta:

Penerbit Pustaka Pelajar

Malik Iskandar. Abdul. 2017. Pengemis dalam Perspektif Struktur-Aktor. Makassar:

Yayasan Inteligensia Indonesia

Nana Syaodih Sukmadinata. 2011. Metode Penelitian Pendidikan. Bandung: Remaja

Rosdakarya 